\section{STUDY OF HAEMATOLOGICAL REFERENCE INTERVALS FOR ASIATIC WILD ASS EQUUS HEMIONUS KHUR}

\author{
R.G. Jani ${ }^{1}$, R.H.Sabapara ${ }^{2}$, C.N.Bhuva ${ }^{3}$ and R.D. Katatra ${ }^{4}$ \\ ${ }^{1}$ Co-ordinator, Wildlife Health, GVC, Anand, Gujarat, India. \\ ${ }^{2}$ Veterinary Officer, Polyclinic, Vadodara, Gujarat, India. \\ ${ }^{3}$ Veterinary, Officer, ${ }^{4}$ Zoo Superintendent, Sakkarbaug Zoo, \\ Junagadh, Gujarat, India.
}

Clinical haematology has a recognized role in the veterinary care of domesticated animals; its importance in most wild species is limited by lack of valid reference values. Such information from clinically healthy animals provide baseline information. Based on these values, the results of sick individuals can be compared and assessed. However, the information on this subject is very limited for Wild Ass (Equus hemionus), hence the present study deals with an objective of haematological study is to obtain a base line data of normal values.
Blood was collected from captive Wild Ass ( 2 males \& 2 females). During the study no changes were made in the routine diet regime and other husbandry practices. General body conditions like alertness, body coat, gait, posture and physical status of the animals were assessed and recorded for individual animals.

According to the physical and clinical status of the animals, they were considered as healthy animals. Approximately $15 \mathrm{ml}$ of blood was withdrawn from the jugular vein in a sterile disposable $20 \mathrm{ml}$ capacity plastic syringe attached with 20 -gauge hypodermic needle. From the collected blood $5 \mathrm{ml}$ of blood was deposited in to a sterile ethylene diamine tetra acetic acid (EDTA) vials (Himedia, Bombay) and were agitated for 15-20 seconds to prevent blood clotting.

Haematological evaluation was performed on whole blood. Blood with anticoagulant was used for determining haemoglobin $(\mathrm{Hb})$ content, packed cell volume (PCV), total erythrocyte count (TEC), total leukocyte count (TLC) and erythrocyte sedimentation rate (ESR).

Haemoglobin estimation was done by Sahil's acid haematin method as described by Wintrobe (1986). Whereas, TEC and TLC were enumerated under microscope using the Neubauer's chamber (Jain, 1986).

PCV was estimated by centrifugation as described by Jain (1986).

Table 1. Haematological values for male and female captive Asiatic Wild Ass

\begin{tabular}{lll}
\hline Parameter & Male $(\mathbf{n}=2)$ Mean \pm SE & Female $(\mathbf{n}=2)$ Mean \pm SE \\
\hline Haemoglobin(Hb.g\%) & $10.47 \pm 0.59$ & $10.01 \pm 0.71$ \\
Packed Cell Volume (PCV \%) & $38.50 \pm 1.83$ & $35.00 \pm 1.93$ \\
Total erythrocyte count (TEC x 10 / cmm) & $6.14 \pm 0.49$ & $6.62 \pm 0.63$ \\
Total leucocyte count (TLC x 103/cmm) & $7625.00 \pm 655.71$ & $6735.000 \pm 395.32^{\star \star}$ \\
MCV fl & $51.28 \pm 1.24$ & $52.85 \pm 0.86$ \\
MCH pg/cell & $14.34 \pm 0.82$ & $14.12 \pm 0.74$ \\
MCHC \% & $31.43 \pm 0.71$ & $29.14 \pm 0.68$ \\
Neutrophils \% & $54.45 \pm 2.8$ & $57.55 \pm 2.8$ \\
Lymphocytes \% & $40.25 \pm 3.19$ & $38.15 \pm 3.19$ \\
Eosinophils \% & $4.25 \pm 0.98$ & $3.75 \pm 0.98$ \\
Monocytes \% & $0.95 \pm 0.15$ & $0.95 \pm 0.15$ \\
ESR mm/hr & $39.95 \pm 2.21$ & $42.44 \pm 1.46^{\star}$ \\
\hline
\end{tabular}

Figures in parenthesis indicate the number of animals, Mean with different superscript differs significantly. ${ }^{*}=$ Significant at $5 \%$ level $(P<0.05)$ and $* *=$ Significant at $1 \%$ level $(\mathrm{P}<0.01)$. MCV - Mean corpuscular volume; $\mathrm{MCH}$ - Mean corpuscular haemoglobin; $\mathrm{MCHC}$ - Mean corpuscular haemoglobin concentration; $\mathrm{N}$ neutrophil; L- lymphocyte; E - eosinophils; M - monocyte; ESR - erythrocyte sedimentation rate. 
ESR was estimated as per the method described by Jain (1986). Blood indices viz., mean corpuscular haemoglobin ( $\mathrm{MCH})$, mean corpuscular haemoglobin concentration (MCHC) and mean corpuscular volume (MCV) were calculated according to the formula described by Swenson and Reece (1996). Blood smears prepared from fresh blood after fixing with ethanol, were stained with haematoxylin-eosin (H \& E) stain. Differential leukocytes counts were performed using H \& E stained blood smears (Jain, 1986).

The animals under the study were thoroughly inspected in their enclosure and after restraining in the squeeze cage they were clinically examined. All the examined animals were found with normal gait-posture, healthy lustrous skin coat and without any apparent clinical abnormalities hence considered as healthy animals.

Mean and standard error (SE) were derived for all parameters and were subjected to comparison between sex using standard statistical formula as described by Snedecor and Cochran (1967).

The mean haemotological parameters are presented in Table 1. The data obtained through this study might be used as a guideline for the interpretation of the values obtained from the analysis of the blood collected from sick animal of the species.

\section{Acknowledgement}

The authors are thankful to the Department of Forests, Gujarat State for granting permission for sample collection and to Gujarat Agricultural University for providing facilities and permission to carry out the study.

\section{References}

Jain, N.C. (1986). Schalm's Veterinary Hematology. $4^{\text {th }}$ edition. Lea and Febiger, Philadelphia, U.S.A.

Snedecor, G.W. and W.G. Cochran (1967). Statistical Methods. Indian edition. Oxford and IBF Publishing Co.

Swenson, M.J. and W.O. Reece (1996). Duke's Physiology of Domestic Animals. $11^{\text {th }}$ edition. Panima Publishing Corporation, New Delhi and Bangalore.

Wintrobe, U.V. (1986). In: Jain, N.C. (editor). Schalm's Veterinary Hematology. $4^{\text {th }}$ edition. Lea and Febiger, Philadelphia, USA.

\section{FIRST HOST RECORD OF EURYTOMA RANJITHI NARENDRAN, 1994}

\author{
Manzoor Hussain Dar, Hem Saxena, P.Q. Rizvi and \\ R.G. Chaudhary
}

Department of Plant Protection, Faculty of Agricultural Sciences, Aligarh Muslim University, Aligarh 202002, India

The Podfly Melanagromyza obtusa Malloch, an important pest of Pigeonpea is very difficult to study and control as most of its life stages are completed and concealed inside the pod. In order to assess the potential parasitoids, a study to determine the occurrence of natural enemies was conducted in the agroclimatic conditions of Kanpur. Three parasitoids were recorded infesting podfly and up to $25 \%$ of the podfly in Pigeonpea were found to be parasitised. These parasitoids were identified as Euderus agromyzae Gangrade (Eulophidae), Ormyrus orientalis Walker (Ormyridae) and Eurytoma ranjithi Narendran, 1994 (Eurytomidae: Hymenoptera). Eurytoma ranjithi Narendran was not recorded earlier on any host. In this study, it was found parasitizing Podfly Melanagromyza obtusa Malloch. Eurytoma species was earlier reported parasitizing M. obtusa by Singh (1982) and Sithanatham et al. (1983). Eyrytoma robusta Mayr group was also recorded from the same host by Sithanantham et al. (1987). Eurytoma ranjithi parasitizing Melanagromyza obtusa Malloch is a first record.

\section{Acknowledgement}

The authors are very grateful to Dr. T.C. Narendran, Department of Zoology, University of Calicut for the identification of the parasitoids.

\section{References}

Narendran, T.C. (1994). Torymidae and Eurytomidae of Indian subcontinent. Zoological Monograph, Department of Zoology, Calicut University publication, 500pp.

Singh, S. (1982). Ecology of the Agromyzidae (Diptera) associated with leguminous crops in India. Memoirs of the school of Entomology, No. 8, St. John's College, Agra, India 126pp.

Sithanantham, S., R.V. Rao and W. Reed (1983). Survey of Pigeonpea Podfly parasites in India. International Pigeonpea Newsletter 2: 66-68. Sithanantham, S., R.V. Rao and W. Reed (1987). Parasites of Pigeonpea Podfly, Melanagromyza obtusa (Malloch), in India. Journal of Biological Control 1(1): 10-16. 